\title{
Comparison of the Structure of Leg and Pectoral Muscles between Lonchura striata and Copsychus saularis
}

Liu Xiaodong ${ }^{1}$, Li Yang ${ }^{3}$, Zhang Sen¹, Xin Hailiang ${ }^{1}$, Mu Pan ${ }^{3}$, Li Jia ${ }^{3}$, Wu Bangyuan²,3

10.18805/IJAR.BF-1442

\begin{abstract}
Background: Bird is important in maintaining biodiversity and its lifestyles and behaviors will pose an important impact on the ecological environment. Birds are also inseparable for ecological stability. Birds' movement and living habits are a widely studied topic. Methods: Two economic valuable birds, Lonchura striata and Copsychus saularis, were selected in this study. It aims at investigating the characteristics of muscle fiber tissues and comparing the differences between male and female species. Histological techniques were used to determine the characteristics of the muscle fiber (diameter, area and density) in leg and pectoral muscles.

Result: There were differences in the muscle fiber characteristics of the Lonchura striata and the Copsychus saularis. The characteristics of muscle fibers between males and females of the same species were significantly different and there were also significant differences in the same parts of different species. The diameter and area of muscle fibers are correlated to the density of muscle fibers. This study suggested that the characteristics of muscle fibers are related to their living habits and population characteristics.
\end{abstract}

Key words: Copsychus saularis, Histological characteristics, Leg muscles, Lonchura striata, Muscle fiber, Pectoral muscles.

\section{INTRODUCTION}

Birds involve in the ecosystem and they have complex movements (Debnath et al., 2018). Two common resident birds belonging to Passeriformes, Lonchura striata and Copsychus saularis, are easy to tame and have certain ornamental value. At present, the research about Lonchura striata in China mainly include behavioral studies focusing on nest site selection, breeding, brooding behavior, domestication (Kagawa et al., 2012) and physiological studies on neural system, hormones, embryonic development and so on (Li et al., 1992; Bao et al., 2005; Nottebohm et al., 1990). There are relatively few studies on Copsychus saularis, mainly on its feeding, breeding and nesting habits (Barnea et al., 1991) and vocal behavior (Jiang et al., 2003). However, the muscle tissue and molecular ecology knowledge of the two birds are lacking. Birds need skeletal muscle to achieve their behaviors and the characteristics of skeletal muscle are associated with the characteristics of muscle fiber tissue. The daily activities of birds are inseparable from pectoral and leg muscle (Torrella et al., 1999). To mind the gap, this study investigated the characteristics of the pectoral muscle and leg muscle, the characteristics of muscle fibers and their influencing factors and the relationship between muscle fibers and movement. It provides basic reference for following muscle and behavioral studies in these two birds.

\section{MATERIALS AND METHOdS}

The experiment was conducted from 2019-3 to 2020-2 at the Key Laboratory of Southwest China Wildlife Resources Conservation, China West Normal University College of Life Science, Nanchong, Sichuan. 10 adult Lonchura striata $\left(50\right.$ ) 5 ) and 10 Copsychus saularis ( $55^{-1}+$ ) were collected from Nanchong City, Sichuan, China. For histological observations, the leg and pectoral muscles were
${ }^{1}$ Qiandongnan Vocational and Technical College for Nationalities, Kaili-556 000, Guizhou, China.

${ }^{2}$ Key Laboratory of Southwest China Wildlife Resources Conservation, College of Life Science, China West Normal University, Nanchong, Sichuan-637000, China.

${ }^{3}$ College of Life Science, China West Normal University, Nanchong, Sichuan-637000, China.

Corresponding Author: Wu Bangyuan, Key Laboratory of Southwest China Wildlife Resources Conservation, China West Normal University College of Life Science, Nanchong, Sichuan637000, China. Email: wubangyuan2008@163.com

How to cite this article: Xiaodong, L., Yang, L., Sen, Z., Hailiang, X., Pan, M., Jia, L. and Bangyuan, W. (2022). Comparison of the Structure of Leg and Pectoral Muscles between Lonchura striata and Copsychus saularis. Indian Journal of Animal Research. DOI: $10.18805 /$ IJAR.BF-1442.

Submitted: 21-09-2021 Accepted: 29-01-2022 Online: 14-02-2022 dissected and fixed in $10 \%$ paraformaldehyde solution. Fixed tissues were processed with routine paraffin embedding technique for $5 \mu \mathrm{m}$ paraffin sections. After that, Haematoxylin and Eosin (H.E) staining procedures were performed to show histological changes: Briefly, the slides were treated by xylene dewaxing, ethanol debenzylation, hydration, washing, hematoxylin staining solution, washing, hydrochloric acid, ammonia water washing, eosin solution restaining, washing, gradient alcohol dehydration and xylene transparency. Then the samples were observed under light microscope (CX50, Olympus, Japan) after sealed with neutral balsam on slides and then take pictures at $400 \times$. Following micrometrical parameters were recorded:

\section{Muscle fiber diameter and area}

Using VideoTest-Master Morphology software to measure, the place where the muscle fiber distributed evenly were 
chosen and measure the diameter and area of the target muscle fiber.

\section{Measurement of the muscle fiber density}

Five intact and clear sites were randomly chosen. The number of muscle fibers at the observed area were then counted for the fiber density size index. The results were shown by the fiber number per square millimeter area.

\section{Data analysis}

Data was analyzed by SPSS analysis software 25.0 and excel 365 . The experimental samples belong to continuous variables and there is no obvious correlation between the variables. The normality test and the homogeneity test of variance on the samples meet the conditions of the independent sample $T$ test, so the independent sample $T$ test is used. There are many influencing factors in the experiment. In order to further analyze the influence of each factor on the properties of muscle fibers, this experiment also uses univariate analysis of variance to understand the relationship between each factor. $\mathrm{P}<0.05$ or $\mathrm{P}<0.01$ means the difference is significant or extremely significant.

\section{RESULTS AND DISCUSSION}

Histological characteristics of muscle fibers in different parts

The diameter and area of the leg muscle fibers of the Lonchura striata and Copsychus saularis are significantly greater than the pectoral muscle fibers $(P<0.01)$, the density of male leg muscle fibers is significantly larger than that of the pectoral muscle fiber $(P<0.01)$, while the leg muscle fiber density is extremely smaller $(P<0.01)$ than the pectoral muscle fibers of Lonchura striata (Fig 1 to 3 ). In the univariate analysis of variance, differences are found in the characteristics of muscle fibers in two parts. There might be two factors causing such difference. Fistly, the life activities of the two parts are different. Lonchura striata and Copsychus saularis are both passerines and songbirds, good at flying. Pectoral muscles are usually involved in fly

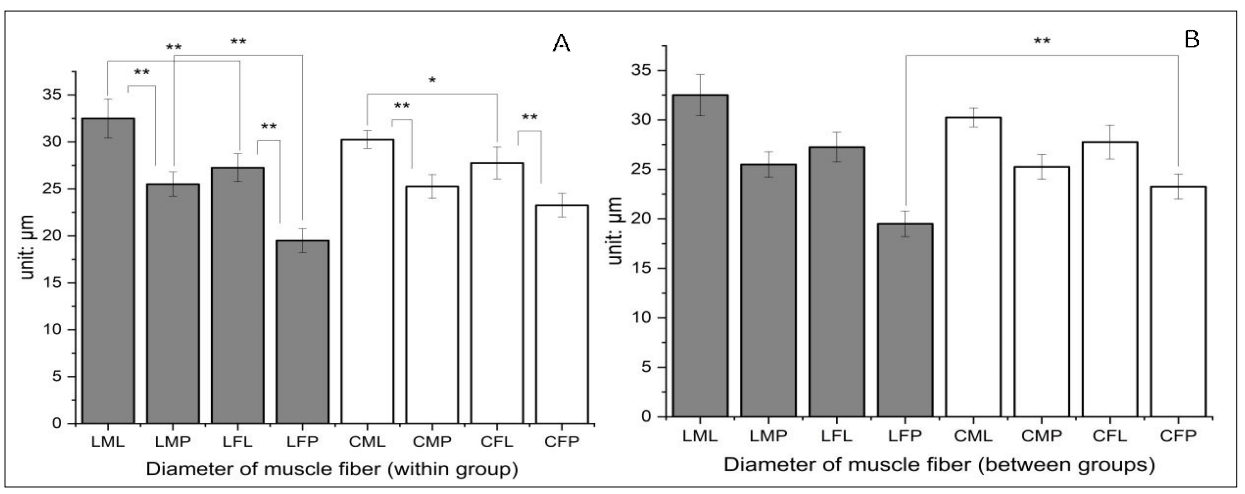

Fig 1: Comparison of muscle fiber diameter $(\mu \mathrm{m})$ A. Compared within group; B. Compared between groups.

LML: Lonchura striata male leg muscles; LMP: Lonchura striata male pectoral muscle; LFL: Lonchura striata female leg muscles; LFP: Lonchura striata female pectoral muscle; CML: Copsychus saularis male leg muscles; CMP: Copsychus saularis male pectoral muscle; CFL: Copsychus saularis female leg muscles; CFP: Copsychus saularis female pectoral muscle. $A$ * indicates significant difference and no * indicates no significant difference.
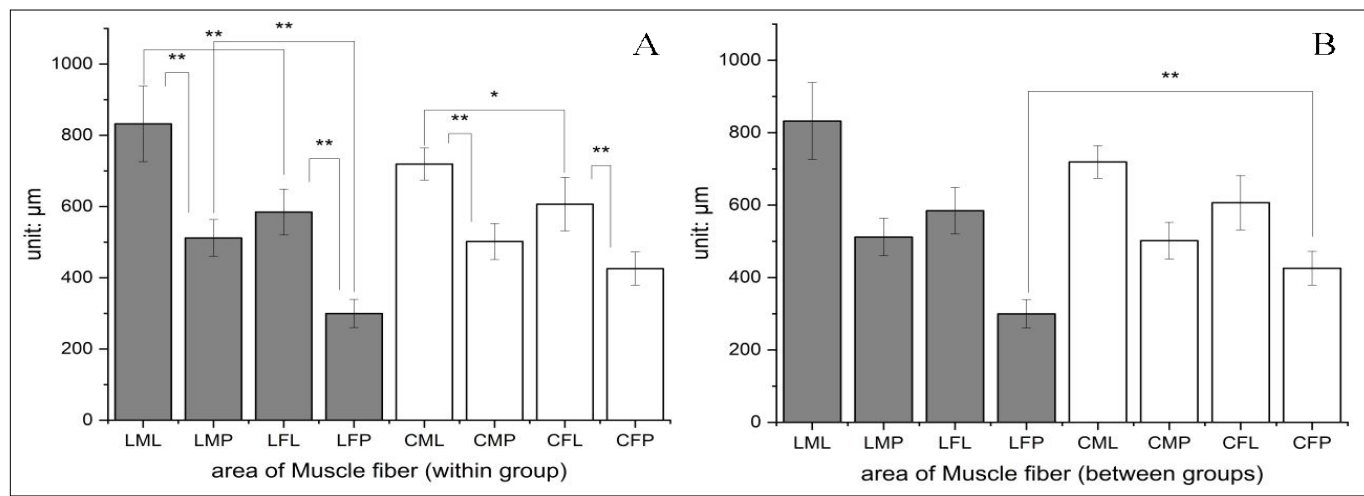

Fig 2: Comparison of muscle fiber area $\left(\mu \mathrm{m}^{2}\right) \mathrm{A}$. Compared within group; B. Compared between groups.

LML: Lonchura striata male leg muscles; LMP: Lonchura striata male pectoral muscle; LFL: Lonchura striata female leg muscles; LFP: Lonchura striata female pectoral muscle; CML: Copsychus saularis male leg muscles; CMP: Copsychus saularis male pectoral muscle; CFL: Copsychus saularis female leg muscles; CFP: Copsychus saularis female pectoral muscle. $A$ * indicates significant difference and no * indicates no significant difference. 
activities which requires for stronger muscle fiber such as the red muscle. The red muscle fiber is thinner and the density is bigger than the common white muscle fiber (Torrella et al., 1998). There are more red muscle fibers in pectoral muscle and the density of pectoral muscle fibers is greater than that of leg muscle fibers, which may prove its better. Secondly, hormone levels will pose different effects on the characteristics of muscle fibers in different parts (Bell et al., 2000) and corresponding to different life activities. Therefore, it will also affect the characteristics of pectoral and leg muscle fibers.

\section{Influence of gender on the histological characteristics of muscle fibers}

The diameter and area of muscle fibers in males are larger than those in females in the same part of Lonchura striata and Copsychus saularis. However, male leg muscle density is lower than it in females, male pectoral muscle density is larger than that in females (Fig 3). The reasons may be related to two aspects: one refers to the different gender division of labor. Males need to undertake the tasks of foraging and defense with more flight activities (Huang et al., 2020). On the other hand, the levels of sex hormones are different in different genders. Different sex leads to different secretion levels of sex hormone and this might cause different growth and development of skeletal muscle. Androgen can stimulate the growth of skeletal muscle and promote protein synthesis (Bell et al., 2000). It is concluded that under certain feeding conditions, gender has a significant impact on the characteristics of muscle fibers. The density of male pectoral muscle fibers is higher and the characteristics of muscle fibers are better than females and the density of leg muscle fiber in females is higher than that in males.

\section{Differences in histological characteristics of muscle fibers among different species}

The diameter and area of pectoral muscle fibers in female Copsychus saularis are significantly larger than those in female Lonchura striata $(P<0.01)$ (Fig 1 and 2$)$. The fiber density of leg muscle of Lonchura striata is less than that of Copsychus saularis and the fiber density of pectoral muscle is greater than that of Copsychus saularis $(P<0.01)$ (Fig 3$)$. The formation process of muscle fibers is complicated, but the development process of muscle fibers of different species is basically the same. However, there are differences among species in regulation of the muscle fiber development. Many core genes and protein families have significant regulatory effects on the composition, energy metabolism and quantity of muscle fibers (Sun et al., 2019; Zhao et al., 2020; Feng et al., 2019). The muscle fiber difference between Lonchura striata and Copsychus saularis may result from different levels of gene regulation, which makes the characteristics of muscle fibers more adapted to the living habits of the corresponding species (Lv et al., 2019; Lang et al., 2020). There are differences in feeding habits and habits between the two birds. Lonchura striata belongs to herbivore and feeds on plant seeds, especially on rice (Huang et al., 2020; Karasov, 1996) and Copsychus saularis mainly feeds on fruits and insects, with different food types due to seasons (Barnea et al., 1991; Yuan and Yan, 2016). The difference in the characteristics of the muscle fibers of two birds may conform to the differences in the living habits.

Influence of species, gender and parts on muscle fiber characteristics

One way ANOVA is used to derive main and interactive effects for the three factors of the data. Main effects can be characterized at multiple levels when assessing one or more factors and assess the effect produced by a certain influence factor on the dependent variable. Data analysis results show that there are differences in the characteristics of muscle fibers among different species, genders and parts and there are interactions between any two factors. In the inter subjective effect test, the $P$ values of species, gender and parts are all less than 0.05 , therefore, all these three factors have significant impact on the density of muscle fibers. Among the interaction effects, the $P$ values of the interaction effects between species and gender, species and parts and gender and parts are all less than 0.05 , which means statistically significant. So, the effect of one of these three factors is affected by the level of the other two factors.

In the interactive effect of species and gender, the muscle fiber density of the two birds in the male is

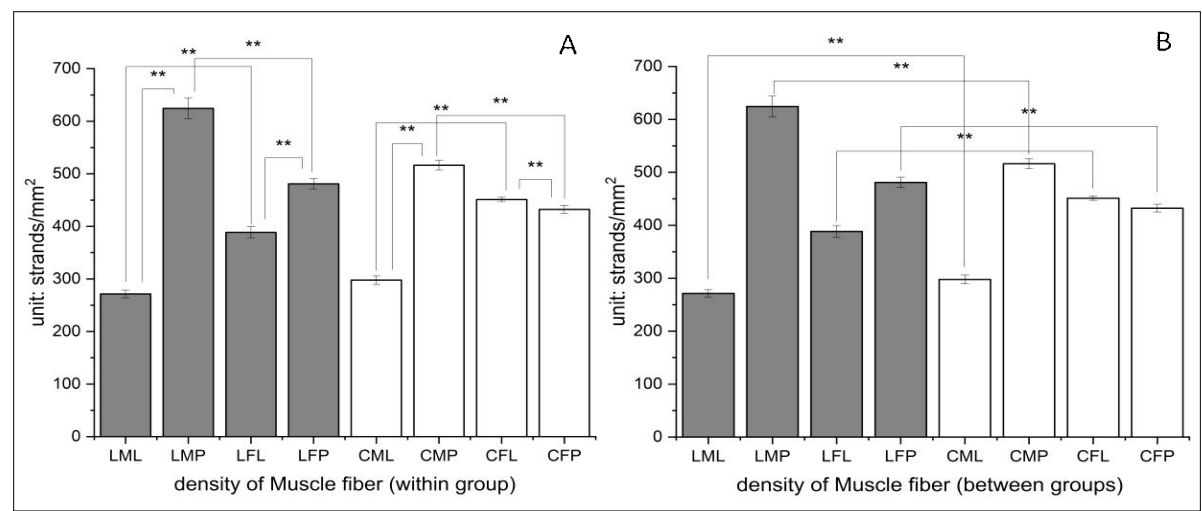

Fig 3: Comparison of muscle fiber density (root $/ \mathrm{mm}^{2}$ ) A. Compared within group; B. Compared between groups. 


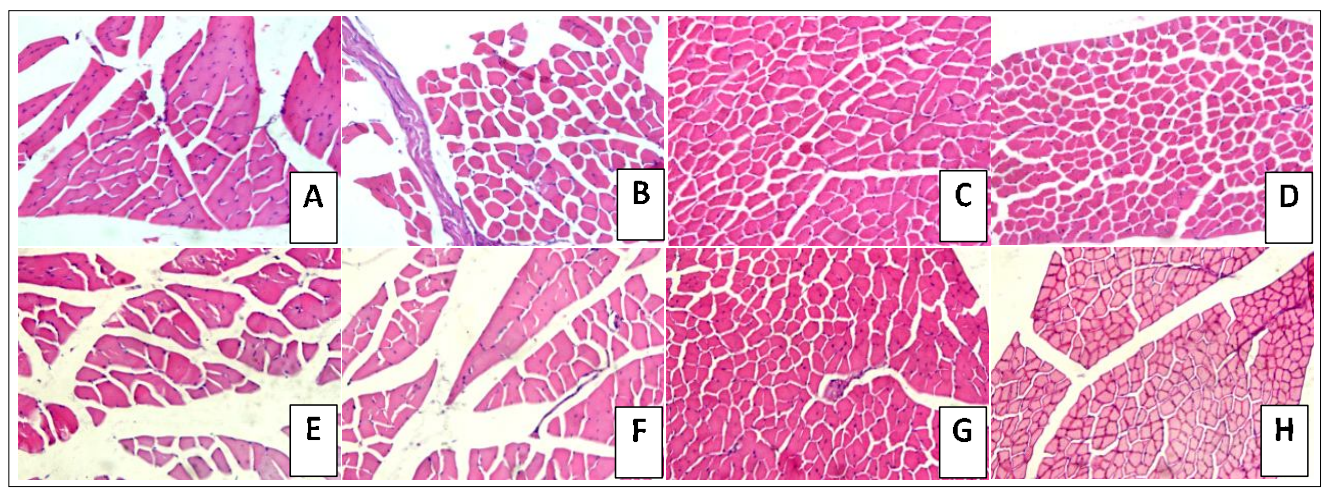

Fig 4: Muscle fiber microstructure of the leg muscle and pectoral muscle of Lonchura striata and Copsychus saularis.

A. Lonchura striata male leg muscle; B. Lonchura striata female leg muscle; C. Lonchura striata male pectoral muscle; D. Lonchura striata female thoracic muscle; E. Copsychus saularis male leg muscle; F. Copsychus saularis female leg muscle; G. Copsychus saularis male pectoral muscle; $\mathrm{H}$. Copsychus saularis female pectoral muscle.

significantly different. The muscle fiber density of Lonchura striata males are lager $(P<0.05)$ than that in Copsychus saularis males, but there is no significant difference of this between the two female species $(P>0.05)$. The male and female differences between the same species of Lonchura striata and Copsychus saularis are significant $(P<0.01)$, but the density of muscle fibers in males of Lonchura striata is extremely greater than that of females $(P<0.01)$, while the density of muscle fibers in males of Copsychus saularis is significantly lower than that of females $(P<0.01)$, which may be related to the division of labor between male and female and the different hormone levels of the two species. Among the interactive effects of species and muscle fiber part, the density of leg and pectoral muscle fibers is significantly different between two bird species. The muscle fiber density of Lonchura striata leg muscle is smaller than that of Copsychus saularis, while the pectoral muscle fiber density is greater. Leg muscles and pectoral are significantly different in each bird. The density of the pectoral muscle is much better than that of the leg muscles and the density of the leg muscles and pectoral muscle are significanltly different in Lonchura striata. In the interactive effects of gender and parts, the leg muscles and pectoral muscles between males and females are significantly different. The leg muscle fiber density of males is lower than that of females, while the pectoral muscle fiber density is greater than that of females. The differences between leg and pectoral muscle in different gender are significant (Fig 4).

In short, there are statistical differences between different species, genders and parts. The second-order interaction effects of the three factors of species, gender and part are statistically significant, while the third-order interaction effects are not statistically significant. It is suggested that all the three influencing factors of species, gender and part have a significant impact on the characteristics of muscle fibers. Meanwhile, each factor also has a certain influence on the effect of the other two factors.

\section{CONCLUSION}

The differences of species, gender and parts have a significant impact on the histological characteristics of muscle fibers and the effects of each influencing factor will be different depending on the different expression levels of the other two factors. The diameter, area and density of muscle fibers can be affected to various degrees, among which the density of muscle fibers is the most sensitive one. The results of this study provides a reference for the investigation of influencing factors of the histological properties in muscle fibers.

Conflict of interest: None.

\section{REFERENCES}

Bao, C.Y., Zeng, L., Sun. Y.Y., Lin, Y.D., Peng, W.M., Zhang, X.W., Zeng, S.J. and Zou, M.X. (2005). Sexually dimorphic expression of the genes in the forebrain vocal-control nucleus RA of juvenile white-rumped munia Lonchura striata by mRNA differential display technique. Acta Zoologica Sinica. 51: 149-155.

Barnea, A., Yomtov, Y. and Friedman, J. (1991). Jstor: Functional Ecology. Functional Ecology. 5: 394-402.

Bell, G.J., Syrotuik, D., Martin, T.P., Burnham, R. and Quinney, H.A. (2000). Effect of concurrent strength and endurance training on skeletal muscle properties and hormone concentrations in humans. European Journal of Applied Physiology. 81: 418-427.

Debnath, S., Biswas, S. and Panigrahi, A. K. (2018). Present status and diversity of avian fauna in purbasthali bird sanctuary, West Bengal, India. Agricultural Science Digest. 38: 95-102.

Feng, H., Li, Z., Cai, Q., Wang, X., Qiao, B., Wang, K., Tang, X. and Liu, A. (2019). Effect of in ovo ornithine-aketoglutarate feeding on early body weight and pectoral muscle development of chicks. Indian Journal of Animal Research. 53: 1679-1683.

Huang, R., Li, L., Song, B. and Wu, B. (2020). Appearance and digestive system comparison of Lonchura striata and Copsychus saularis: Searching for the effect of staple feeding ingredients on avian morphology. Revista Brasileira de Ciência Avícola. 22: 1-8. 
Jiang, S.R. (2003). Vocal behavior of magpie robin (Copsychus saularis) in hangzhou, China. Sichuan Journal of Zoology. 22: $144-146$

Kagawa, H., Yamada, H., Lin, R.S., Mizuta, T., Hasegawa, T. and Okanoya, K. (2012). Ecological correlates of song complexity in white-rumped munias: The implication of relaxation of selection as a cause for signal variation in birdsong. Interaction Studies. 13: 263-284.

Karasov, W.H. (1996). Digestive Plasticity in Avian Energetics and Feeding Ecology [M]. In: Avian Energetics and Nutritional Ecology. [Carey C. (eds)]. Springer, Boston, MA. pp. 61-84.

Lang, Y.M., Zhang, S.S., Xie, P., Yang, X., Sun, B. and Yang, H. (2020). Muscle fiber characteristics and postmortem quality of longissimus thoracis, psoas major and semitendinosus from Chinese Simmental bulls. Food Science and Nutrition. 8: 6083-6094.

Li, D.F., Zuo, M.X., Lan, S.C. and Hu, J. (1992). Sex differences of vocal control nuclei in the forebrain of songbirds. Acta Zoologica Sinica. 38: 298-301.

Lv, C., Niu, S., Yan, S., Bai, C., Yu, X., Hou, J., Gao, W., Zhang, J., Zhao, Z. and Yang, C. (2019). Low-density lipoprotein receptor-related protein 1 regulates muscle fiber development in cooperation with related genes to affect meat quality. Poultry Science. 98: 3418-3425.
Nottebohm, F., Alvarez-Buylla, A., Cynx, J., Kirn, J., Ling, C.Y., Nottebohm, M., Suter, R., Tolles, A. and Williams, H. (1990). Song learning in birds: the relation between perception and production. Philosophical Transactions of the Royal Society of London. 329: 115-124.

Sun, Y.Y., Fu, S.Y., He, X.L., Wang, B., Duan, S., Liu, Y.B. and Zhang, W.G. (2019). Characteristics of the myofiber development of meat livestock and poultry. Journal of China Agricultural University. 24: 78-85.

Torrella, J.R., Fouces, V. and Viscor, G. (1999). Descriptive and functional morphometry of skeletal muscle fibres in wild birds. Canadian Journal of Zoology. 77: 724-736.

Torrella, J.R., Fouces, V., Palomeque, J. and Viscor, G. (1998). Comparative skeletal muscle fibre morphometry among wild birds with different locomotor behaviour. Journal of Anatomy. 192: 211-222.

Yuan, B.D. and Yan, Y.F. (2016). Feeding Niche of Copsychus saularis between Spring and Winter. Sichuan Journal of Zoology. 35: 426-430.

Zhao, Y., Cao, G., Gao, P., Jia, G. and Meng, J. (2020). Comparing the mrna expression profile of psoas major and Longissimus dorsi muscles in pig. Indian Journal of Animal Research. 54: 1490-1496. 